\title{
Communication skills amidst stakeholders upon higher education based in Manta gauging withal assessing interpersonal skills, whereto appraising societal conveyance on contemporary wonted milieu
}

Ace Earnberg ${ }^{1}$

${ }^{1}$ Affiliation not available

October 19, 2021

\begin{abstract}
This study was aimed at investigating the conflicts that may occur on the part of university students at ULEAM where it was reflected whether in the university effective communication skills are built within the classroom, all through assessment instruments that determine the degree of skills in terms of communication as in interpersonal relationships. This study did provide support to issues in the university environment in the construction by making aware of the impact of an active learning environment, seeing how receptive students are to the topics covered in class and how the follow-up of the course is developed by the teacher by dealing with the difficulties students had in improving the communication of knowledge with better studentteacher interactions.
\end{abstract}

\section{Hosted file}

Communication_skills_amidst_stakeholders_upon_higher_education (2).pdf available at https: //authorea.com/users/399625/articles/540253-communication-skills-amidst-stakeholdersupon-higher-education-based-in-manta-gauging-withal-assessing-interpersonal-skillswhereto-appraising-societal-conveyance-on-contemporary-wonted-milieu 